\title{
Middle Miocene carnivorans from the Monarch Mill Formation, Nevada
}

Kent Smith, Nicholas Czaplewski, and Richard Cifelli

Acta Palaeontologica Polonica 61 (1), 2016: 231-252 doi:http://dx.doi.org/10.4202/app.00111.2014

The lowest part of the Monarch Mill Formation in the Middlegate basin, west-central Nevada, has yielded a middle Miocene (Barstovian Land Mammal Age) vertebrate assemblage, the Eastgate local fauna. Paleobotanical evidence from nearby, nearly contemporaneous fossil leaf assemblages indicates that the Middle Miocene vegetation in the area was mixed coniferous and hardwood forest and chaparral-sclerophyllous shrubland, and suggests that the area had been uplifted to $2700-2800 \mathrm{~m}$ paleoaltitude before dropping later to near its present elevation of 1600 $\mathrm{m}$. Thus, the local fauna provides a rare glimpse at a medium- to high-altitude vertebrate community in the intermountain western interior of North America. The local fauna includes the remains of fish, amphibians, reptiles, birds, and 25 families of mammals. Carnivorans, the focus of this study, include six taxa (three of which are new) belonging to four families. Canidae are represented by the borophagine Tomarctus brevirostris and the canine Leptocyon sp. indet. The earliest record and second North American occurrence of the simocyonine ailurid Actiocyon is represented by A. parverratis sp. nov. Two new mustelids, Brevimalictis chikasha gen. et sp. nov. and Negodiaetictis rugatrulleum gen. et sp. nov., may represent Galictinae but are of uncertain subfamilial and tribal affinity. The fourth family is represented by the felid Pseudaelurus sp. indet. Tomarctus brevirostris is limited biochronologically to the Barstovian land mammal age and thus is consistent with the age indicated by other members of the Eastgate local fauna as well as by indirect tephrochronological dates previously associated with the Monarch Mill Formation. Actiocyon parverratis sp. nov. extends the temporal range of the genus Actiocyon from late Clarendonian back to the Barstovian. The Eastgate local fauna improves our understanding of mammalian successions and evolution, during and subsequent to the Mid-Miocene Climatic Optimum ( 14-17 Ma).

Key words: Mammalia, Mustelidae, Canidae, Ailuridae, Felidae, Miocene, Barstovian, Nevada.

Kent Smith [kent.smith@okstate.edu], OSU-Center for Health Sciences, 1111 W 17th Street Tulsa, OK 74107, USA; Nicholas Czaplewski [nczaplewski@ou.edu] and Richard Cifelli [rlc@ou.edu], Sam Noble Oklahoma Museum of Natural History, 2401 Chautauqua, Avenue, Norman, OK 73072, USA. 
This is an open-access article distributed under the terms of the Creative Commons

Attribution License (for details please see creativecommons.org), which permits unrestricted use, distribution, and reproduction in any medium, provided the original author and source are credited.

FoF 